\title{
Interspecific and intraspecific composition and variation of free amino acids in marine phytoplankton
}

\author{
V. Martin-Jézéquel ${ }^{1}$, S. A. Poulet ${ }^{1}$, R. P. Harris ${ }^{2}$, J. Moal $^{3}$, J. F. Samain ${ }^{3}$ \\ ${ }^{1}$ CNRS, Station Marine, F-29211 Roscoff, France \\ ${ }^{2}$ Marine Biological Association, Citadel Hill, Plymouth PLI 2PB, United Kingdom \\ ${ }^{3}$ IFREMER, Centre de Brest, BP 337, F-29273 Brest cédex, France
}

\begin{abstract}
Concentration and variation of 16 free amino acids were measured in the internal and external pools of 11 marine phytoplankton species belonging to 5 taxonomic classes in culture. Changes detected in each pool were related to both the species, classes and phases of growth. The intracellular and extracellular pools had a different composition. The internal pool was characterized by aspartic acid, glutamic acid, serine, glutamine and leucine, which accounted for $>70 \%$ of the total concentration. The extracellular pool was characterized by serine, glycine, leucine and lysine, accounting for $>70 \%$ of the total concentration. The proportions and combinations of these compounds were variable and enabled the species and classes of phytoplankton to be grouped according to their internal and external amino acids content. The abundance and flux of free amino acids seem to be related to both the size, biomass and metabolic activity and the growth conditions of the phytoplankton.
\end{abstract}

\section{INTTRODŨCTIOTN}

Although carbon and nitrogen are useful parameters in the study of the properties and dynamics of dissolved organic matter in seawater, specific molecules, such as amino acids, are known compounds involved in various biological and physiological processes in plankton. Laanbroek et al. (1985) reviewed the implications of these compounds at various steps of the marine food web.

In the pelagic ecosystem, bacteria are known producers and consumers of dissolved amino acids (e.g. Lancelot \& Billen 1984, Carlucci et al. 1986). Zooplankton are also known to produce amino acids through excretion (Webb \& Johannes 1967), fecal production (Poulet et al. 1986) and presumably through 'sloppy feeding (Lampert 1978, Williams \& Poulet 1986). According to Braven et al. (1984), the total concentration of dissolved amino acids in seawater can account for 13 to $30 \%$ of the total dissolved nitrogen. This pool probably reflects the balance between release and uptake processes, due to the physiological activity of bacteria (Fuhrman 1987) and phytoplankton (Flynn \& Butler 1986). Amino acids can also be released in seawater by decay of senescent phytoplankton cells (Fogg 1983). Chlorophyll a, used as an index of the phytoplankton biomass, and free amino acids in seawater are sometimes not correlated, or may be negatively correlated (Jørgensen 1982, Keller et al. 1982, Macko \& Green 1982, Poulet et al. 1985). Therefore, it appears that the contribution of phytoplankton alone to the flux of amino acids in seawater may be masked by the activity of the other contributors (Poulet et al. unpubl.).

Laboratory experiments allow a more accurate estimation of the contribution of phytoplankton to the pool of dissolved free amino acids (Hammer \& Eberlein 1981, Hammer \& Brockmann 1983, Poulet \& MartinJézéquel 1983, Admiraal et al. 1984, 1986). Is the intracellular pool of free amino acids characteristic of particular species? Is it reflected by the extracellular pool measured in the culture medium, or in seawater? Previous results (Parsons et al. 1961, Chau et al. 1967, Daumas 1976, Enright et al. 1986) have shown that amino acid composition was similar, regardless of the species and size of the phytoplankton. These results were obtained after hydrolysis of the samples, and were related to total amino acids (combined plus free), reflecting the composition of protein (combined fraction) rather than the free amino acids pool alone. The extraction and analytical procedures of high perform- 
ance liquid chromatography (e.g. Lindroth \& Mopper 1979, Liebezeit 1985) allow detection of traces of dissolved free amino acids, both inside and outside cells.

This paper examines and compares the composition of the intra- and extracellular pools of water-soluble free amino acids of 11 species of algae, cultivated under similar conditions, and belonging to 5 classes of marine phytoplankton.

\section{METHODS}

The strains of the phytoplankton algae were obtained from the Marine Biological Association culture collection (Plymouth, UK), and belong to 5 taxonomic classes: Bacillariophyceae (Thalassiosira rotula, Thalassiosira weissflogii, Skeletonema costatum, Coscinodiscus wailesii); Cryptophyceae (Cryptomonas appendiculata, Cryptomonas maculata); Dinophyceae (Gyrodinium aureolum, Gymnodinium simplex, Scrippsiella trochoidea); Chlorophyceae (Dunaliella tertiolecta) and Haptophyceae (Isochrysis galbana). The non-axenic cultures were grown in batch under continuous light illumination; the medium was made using natural seawater, prefiltered on $0.22 \mu \mathrm{m}$ Millipore filters and enriched with nitrates, phosphates, silicates, metals and vitamins, as in the $f / 2$ medium of Guillard \& Ryther (1962), without Tris or any other element (see Moal et al. 1987 for details). Samples for dissolved free amino acids (DFAA) were collected at the same times as replicate samples analysed for a complementary biochemical study (Moal et al. 1987).

For the intracellular pool of DFAA, $10 \mathrm{ml}$ from each culture were sampled at 2 periods of growth (active growth, corresponding to the exponential phase; reduced growth, corresponding to the stationary phase see Moal et al. 1987 for details). They were gently syringed on Millipore filters $(0.45 \mu \mathrm{m}$; diameter $23 \mathrm{~mm})$ to prevent breakage of the cells (Fuhrman \& Bell 1985) and stored at $-20^{\circ} \mathrm{C}$ without washing. The cell-free culture medium was collected at the same time, and frozen in acid-washed vials for analysis of the extracellular pool of DFA.A. Extraction of the intracellular DFAA was achieved in $1 \mathrm{ml}$ ultra-clean distilled water after grinding the filters in a tissue grinder, centrifuging for $5 \mathrm{~min}$ at $3000 \mathrm{rpm}$ and collecting the supermatant, just prior to the analysis. Sixteen free amino acids (ASP: aspartic acid; GLU: glutamic acid; ASN: asparagine; SER: serine; GLN: glutamine; HIS: histidine; GLY glycine; ARG: arginine; ALA: alanine; TYR: tyrosine; ABA: $\alpha$-aminobutyric acid; VAL: valine; PHE: phenylalanine; LEU: leucine; ORN: ornithine; LYS: lysine) were analysed, using a reversed phase high performance liquid chromatography technique as described by Lindroth \& Mopper (1979) and Dawson et al. (1985). A test of similarity (Clifford \& Stephenson 1975) was used to compare molar percentages in the intra- and extracellular amino acids pools of the phytoplankton.

\section{RESULTS}

\section{Intracellular pool of free amino acids}

The total concentration of free amino acids in the intracellular pool was measured at 2 phases of growth (Table 1). The cell concentration of DFAA (nmol cell-1) was obviously species dependent, whereas the volume concentration (nmol $\mu^{-3}$; calculated by dividing by the cell volume) was in general inversely proportional to the volume of the cell (except for Dunaliella tertiolecta). The amount of DFAA tended to decrease from the active to the reduced phase of growth. In order, Cryptrophyceae, Dinophyceae (except Scrippsiella trochoidea), Haptophyceae, Bacillariophyceae and Chlorophyceae contained decreasing amounts of DFAA per unit cellular volume.

The relative concentration of each amino acid forming part of the intracellular pool (Fig. 1) was not uniform with regard to either species or phase of growth. These results reflect the variability of the pool of DFAA in phytoplankton. In general, 2 to 5 amino acids out of the 16 studied were responsible for $70 \%$ or more of the total concentration. They were ASP, GLU, SER, GLN and LEU. These few amino acids were species dependent; combined, they characterize the 'chemical print' of each alga. Among the secondary group of amino acids, accounting for $30 \%$ or less of the total concentration, in decreasing order of abundance, GLY, ARG, ALA, TYR, VAL, ORN, LYS and PHE. HIS and $A B A$ were undetectable in the majority of the samples (Fig. 1). Some amino acids were detected in a few algae, such as HIS in Skeletonema costatum and Scrippsiella trochoidea, TYR in Gyrodinium aureolum, ARG in S. trochoidea and Gymnodinium simplex, and $\mathrm{PHE}$ in the 4 species of Bacillariophyceae.

A similarity test (Clifford \& Stephenson 1975) was made on the 11 species during their phases of growth, based on their amino acid compositions (Fig. 2). The higher the value of the index, the greater the similarity between the species. Results in Figs. 1 and 2 enabled the species to be grouped according to their biochemical composition. Bacillariophyceae and Haptophyceae had similar compositions, characterized by ASP, GLU, GLN, ALA and TYR (similarity: 62 to $95 \%$ ). Among the Cryptophyceae (Cryptomonas appendiculata) and Chlorophyceae, similar compositions were also observed, characterized by ASP, GLU, SER, GLY, ALA, TYR, VAL and LEU (similarity: 60 to 
Table 1. Total concentration of intracellular free amino acids, measured in 11 species of phytoplankton during the exponential and stationary phases of growth

\begin{tabular}{|c|c|c|c|c|c|}
\hline \multirow[t]{2}{*}{ Class and species } & \multirow{2}{*}{$\begin{array}{l}\text { Cell volume } \\
\qquad\left(\mu \mathrm{m}^{3}\right)\end{array}$} & \multicolumn{2}{|c|}{ Exponential phase } & \multicolumn{2}{|c|}{ Stationary phase } \\
\hline & & $\begin{array}{l}\text { nmol cell } \\
\quad \times 10^{-6}\end{array}$ & $\begin{array}{l}\text { nmol } \mu^{-3} \\
\times 10^{-9}\end{array}$ & $\begin{array}{l}\mathrm{nmol} \mathrm{cell} \\
\quad \times 10^{-6}\end{array}$ & $\begin{array}{l}\mathrm{nmol} \mu \mathrm{m}^{-3} \\
\quad \times 10^{-9}\end{array}$ \\
\hline \multicolumn{6}{|l|}{ Bacillariophyceae } \\
\hline Thalassiosira rotula & 14250 & 111 & 7.78 & 113 & 7.90 \\
\hline Thalassiosira weissflogii & 1130 & 57 & 50.40 & 20 & 18.23 \\
\hline Skeletonema costatum & 402 & 6 & 14.92 & 2 & 4.70 \\
\hline Coscinodiscus wailesui & 3328525 & 90000 & 27 & 30000 & 9 \\
\hline \multicolumn{6}{|l|}{ Dinophyceae } \\
\hline Gyrodinium aureolum & 6709 & 450 & 67 & 380 & 56 \\
\hline Gymnodinium simplex & 230 & 14 & 60.80 & 8 & 34.70 \\
\hline Scrippsiella trochoidea & 9600 & 145 & 15.10 & 55 & 5.70 \\
\hline \multicolumn{6}{|l|}{ Cryptophyceae } \\
\hline Cryptomonas maculata & 395 & 50 & 126 & 65 & 165 \\
\hline Cryptomonas appendiculata & 369 & 50 & 135 & 16 & 43 \\
\hline \multicolumn{6}{|l|}{ Chlorophyceae } \\
\hline Dunaliella tertiolecta & 230 & 1 & 4.34 & 2 & 8.26 \\
\hline \multicolumn{6}{|l|}{ Haptophyceae } \\
\hline Isochrysis galbana & 31 & 1.6 & 51.61 & 0.98 & 31.61 \\
\hline
\end{tabular}

$80 \%$ ). The Dinophyceae species had the most variable intracellular pool (similarity: $<60 \%$ ), with Scrippsiella trochoidea having a 'chemical print' similar to Bacillariophyceae and Haptophyceae, while the other 2 species of this class (Gyrodinium aureolum and Gymnodinium simplex) were characterized by LEU in addition to ASP, GLU, GLN, ALA, and TYR. The DFAA compositions of species Bacillariophyceae, Dinophyceae (S. trochoidea), Cryptophyceae, Chlorophyceae and Haptophyceae were quite stable during the 2 periods of growth, as demonstrated by the high values of the similarity index $(60$ to $90 \%)$. However, 2 members of the Dinophyceae $(G$. aureolum and $G$. simplex) and 1 member of the Cryptophyceae (Cryptomonas maculata) showed consistent differences between the phases of growth (similarity: $<60 \%$; Figs, 1 and 2).

\section{Extracellular pool of free amino acids}

Total DFAA concentration ( mmol 1 $^{-1}$ ) measured in the extracellular pool (i.e. culture medium) increased from the exponential to the stationary phase by 8 to $415 \%$, or decreased by 50 to $80 \%$ of the initial concentration, depending on the species. These values represent the net concentration, resulting from the balance between absorption and release of amino acids (Table 2). The highest amino acid concentration was found in the culture medium of Chlorophyceae, followed (in order) by Cryptophyceae, Haptophyceae, Bacillariophyceae and Dinophyceae. These differences were probably related to the density and physiological activity of the cells, as shown by the flux values, estimated between the 2 periods of growth (Table 2). The smallest species (Haptophyceae, Chlorophyceae and Cryptophyceae; Table 1) had the highest biomass in conjunction with the highest flux of amino acids (Table 2). Therefore, cell size and biomass seem to be relevant factors controlling the DFAA flux.

Net flux for the Bacillariophyceae was negative or lower than that observed for the other classes. With the exceptions of Thalassiosira weissflogii and Skeletonema costatum, all species contributed to an accumulation of DFAA in their culture medium. In Coscinodiscus wailesii, despite its larger size (Table 1), flux of amino acids was not exceptionally high, probably because of its low rate of growth.

The relative DFAA compositions in the extracellular pool are shown in Fig. 3. GLU, SER, GLN, GLY, LEU and LYS accounted for more than $70 \%$ of the total concentration; the proportion of these compounds varied among the species. Among the 10 minor amino acids which formed $30 \%$ or less of the concentration, HIS and ORN were undetectable in most of the culture media.

A similarity test enabled the species to be grouped according to the DFAA composition of the culture medium (Fig. 4). A similarity index of $>70 \%$ was calculated between the Bacillariophyceae and the Dinophyceae, and $53 \%$ between the Chlorophyceae and the Haptophyceae. The DFAA pools in the culture medium of the Bacillariophyceae and Dinophyceae were different from those observed in the Chlorophy- 

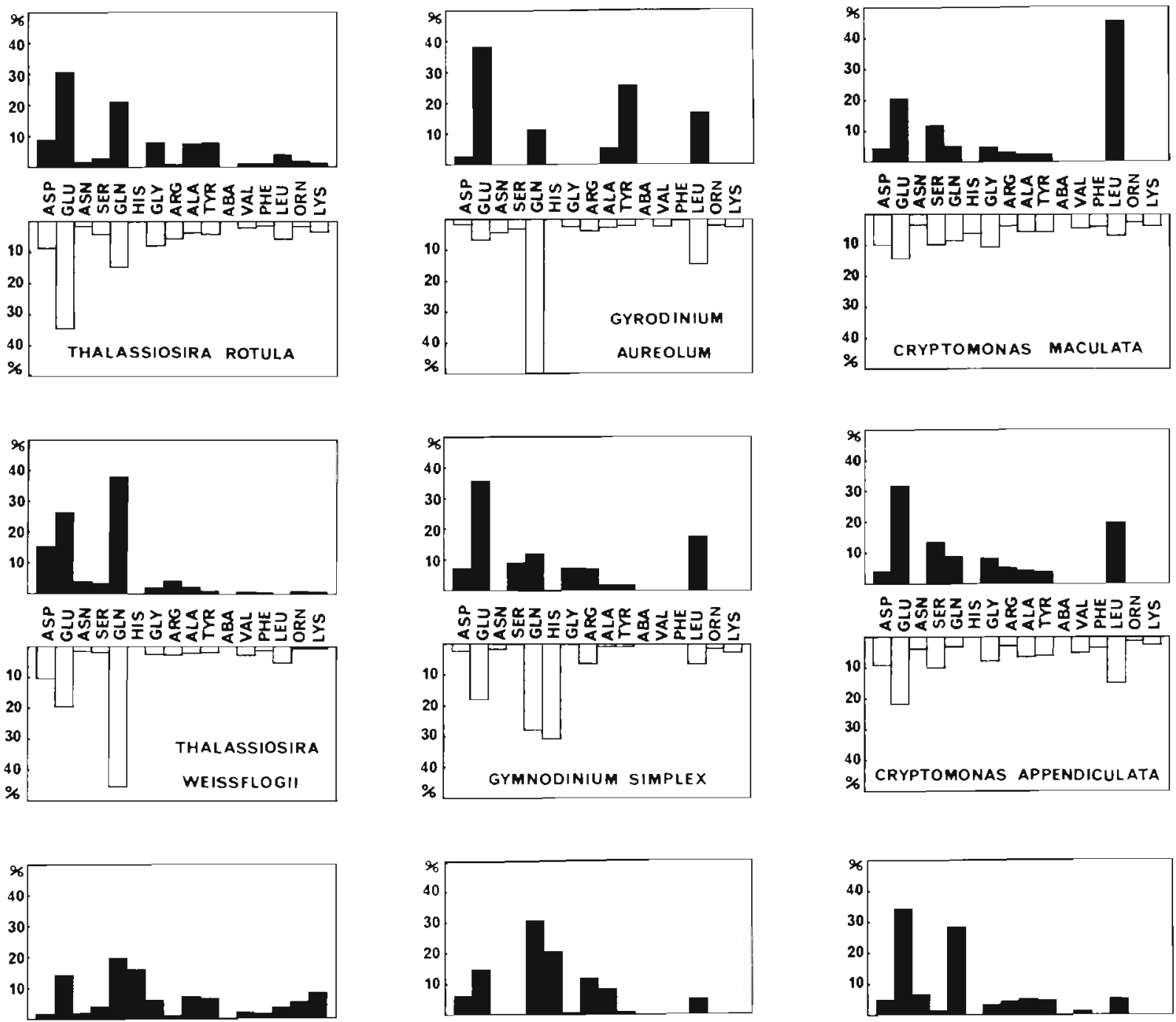

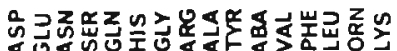
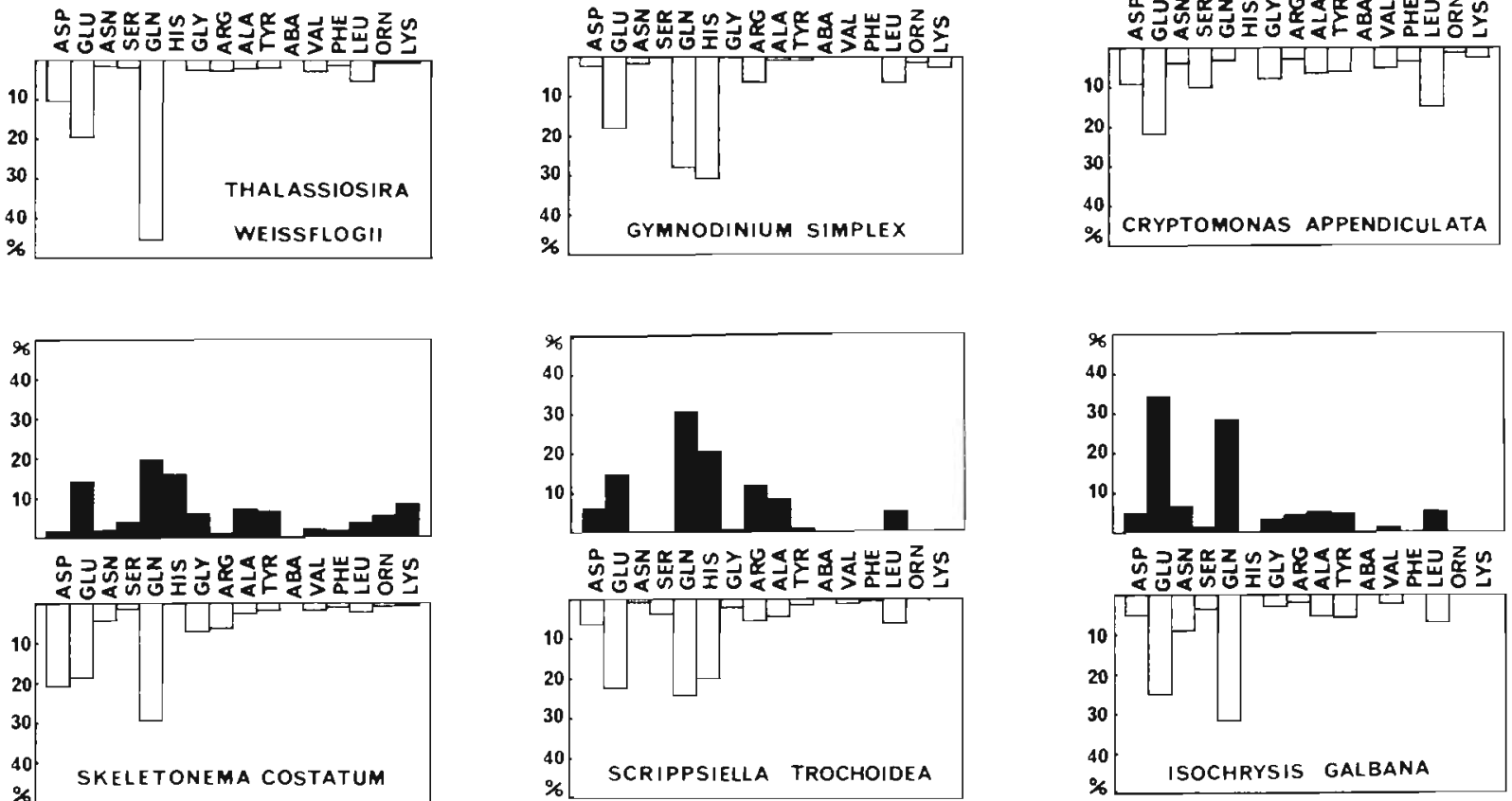

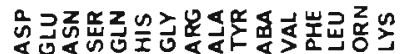
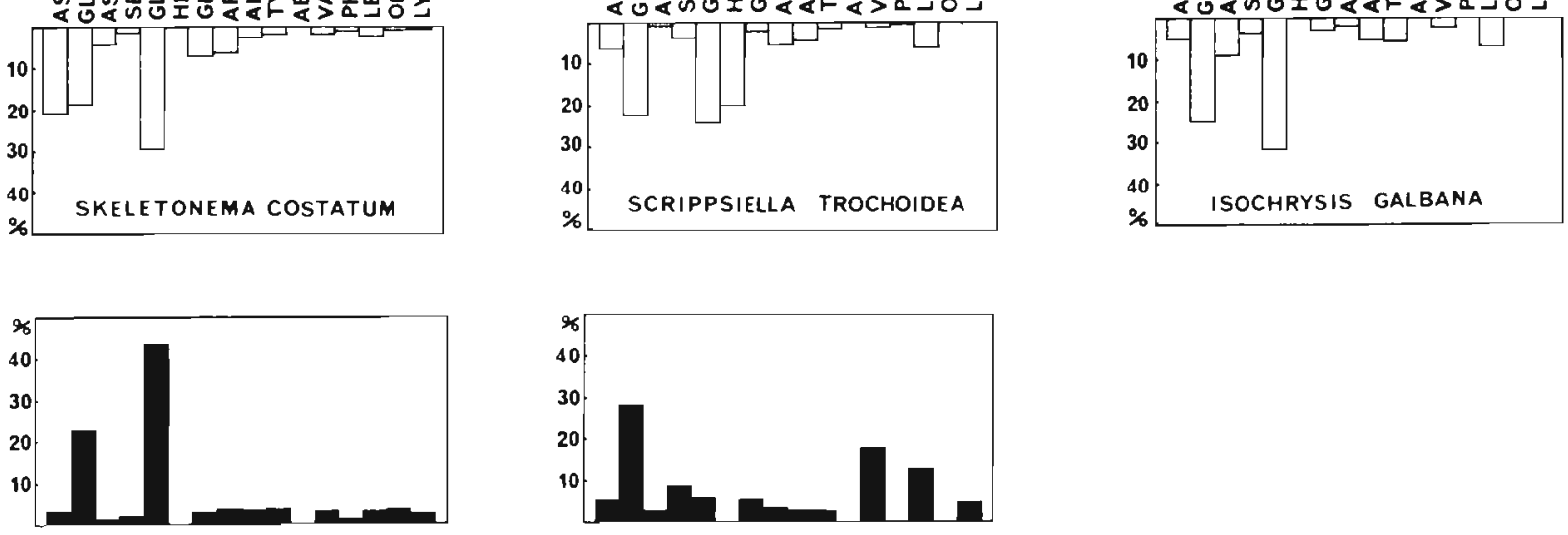

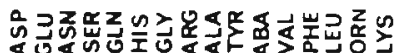

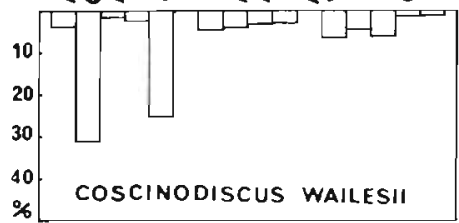

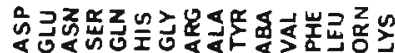

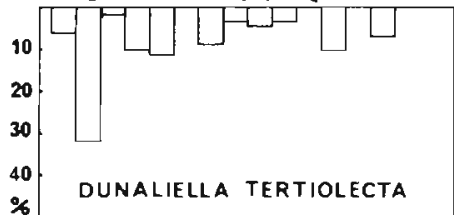

Fig. 1 Intracellular composition of 16 dissolved free amino acids, expressed as molar percentage, during 2 periods of growth of 11 species of phytoplankton. Black bars (upwards): exponential phase; open bars (downwards): stationary phase 
INTRACELLULAR POOL

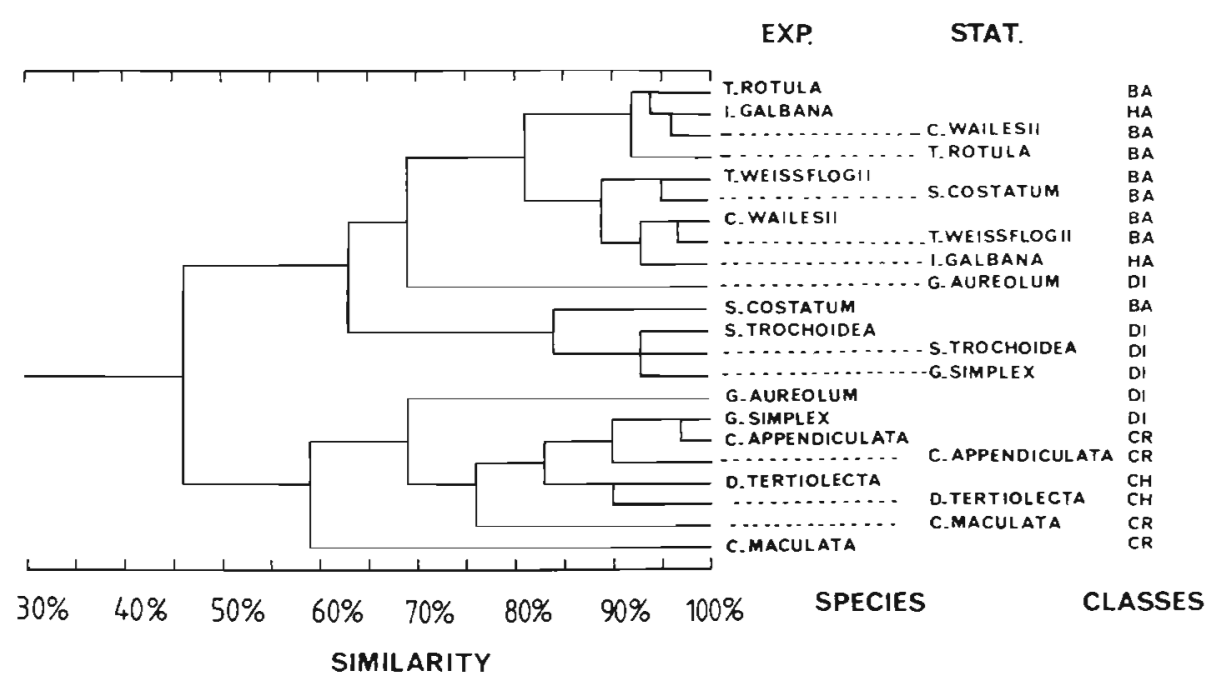

Fig. 2. Test of similarity, comparing intracellular dissolved free amino acids (as in Fig. 1) of 11 species of phytoplankton during the exponential (EXP.) and stationary (STAT.) phases of growth. Taxonomic classes: BA, Bacillariophyceae; DI, Dinophyceae; CR, Cryptophyceae; $\mathrm{CH}$, Chlorophyceae; HA, Haptophyceae

ceae and Haptophyceae (similarity $=22 \%$ ). Thus, the DFAA composition of the external pool varied according to both the class of phytoplankton and the growth phase (Fig. 4). The temporal variability was species specific: for example, Thalassiosira weissflogii, Cryptomonas appendiculata and $C$. maculata had the most variable extracellular DFAA composition (similarity $<40 \%$; Fig. 4), whereas Gyrodinium aureolum and Dunaliella tertiolecta had a more stable composition (similarity $>85 \%$; Fig. 4).

\section{DISCUSSION}

Measurements of the composition and variation of the DFAA (Tables 1 and 2; Figs. 1 and 3) add some complementary information to the biochemistry of the 11 species of phytoplankton reported by Moal et al. (1987).

It appears that the intracellular pools of combined amino acids (Parsons et al. 1961, Chau et al. 1967. Daumas 1976, Enright et al. 1986) and free amino acids

Table 2. Total concentration of free amino acids and phytoplankton biomass, measured in the culture media of the 11 species, during 2 phases of growth. Flux of amino acids has been estimated for each species between the 2 phases of growth (time-lag between phases: 4 to $13 d_{i}$ see Moal et al. [1987] for details)

\begin{tabular}{|c|c|c|c|c|c|c|}
\hline \multirow[t]{2}{*}{ Class and species } & \multicolumn{2}{|c|}{ Exponential phase } & \multicolumn{2}{|c|}{ Stationary phase } & \multicolumn{2}{|c|}{ Flux of DFAA } \\
\hline & $\begin{array}{c}\mathrm{nmol}^{-1} \\
\mathrm{DFAA}\end{array}$ & cells $1^{-1} \times 10^{5}$ & $\begin{array}{c}\mathrm{nmol}^{-1} \\
\mathrm{DFAA}\end{array}$ & cells $l^{-1} \times 10^{5}$ & $\begin{array}{l}\text { nmol cell }-1 \\
d^{-1} \times 10^{-7}\end{array}$ & $\begin{array}{l}\mathrm{nmol} \mu \mathrm{m}^{-3} \\
\mathrm{~d}^{-1} \times 10^{-10}\end{array}$ \\
\hline \multicolumn{7}{|l|}{ Bacillariophyceae } \\
\hline Thalassiosira rotula & 384 & 116 & 416 & 257 & 3.7 & 0.26 \\
\hline Thalassiosira weissflogii & 761 & 155 & 106 & 1090 & -10 & -8.84 \\
\hline Skeletonema costatum & 399 & 5010 & 198 & 22600 & -0.19 & -0.47 \\
\hline Coscinodiscus wailesï & 316 & 0.11 & 657 & 0.35 & 23600 & 7.09 \\
\hline \multicolumn{7}{|l|}{ Dinophyceae } \\
\hline Gyrodinium aureolum & 337 & 4 & 815 & 63 & 62 & 9.24 \\
\hline Gymnodinium simplex & 295 & 180 & 550 & 1240 & 2.6 & 11 \\
\hline Scrippsiella trochoidea & 242 & 165 & 860 & 650 & 9.8 & 1.02 \\
\hline \multicolumn{7}{|l|}{ Cryptophyceae } \\
\hline Cryptomonas maculata & 1271 & 38 & 2610 & 2100 & 5.9 & 14 \\
\hline Cryptomonas appendiculata & 455 & 22 & 2343 & 478 & 46 & 124 \\
\hline \multicolumn{7}{|l|}{ Chlorophyceae } \\
\hline Dunaliella tertiolecta & 1895 & 3490 & 2725 & 5540 & 10 & 43 \\
\hline \multicolumn{7}{|l|}{ Haptophyceae } \\
\hline Isochrysis galbana & 839 & 7170 & 2114 & 21900 & 1.7 & 54 \\
\hline
\end{tabular}



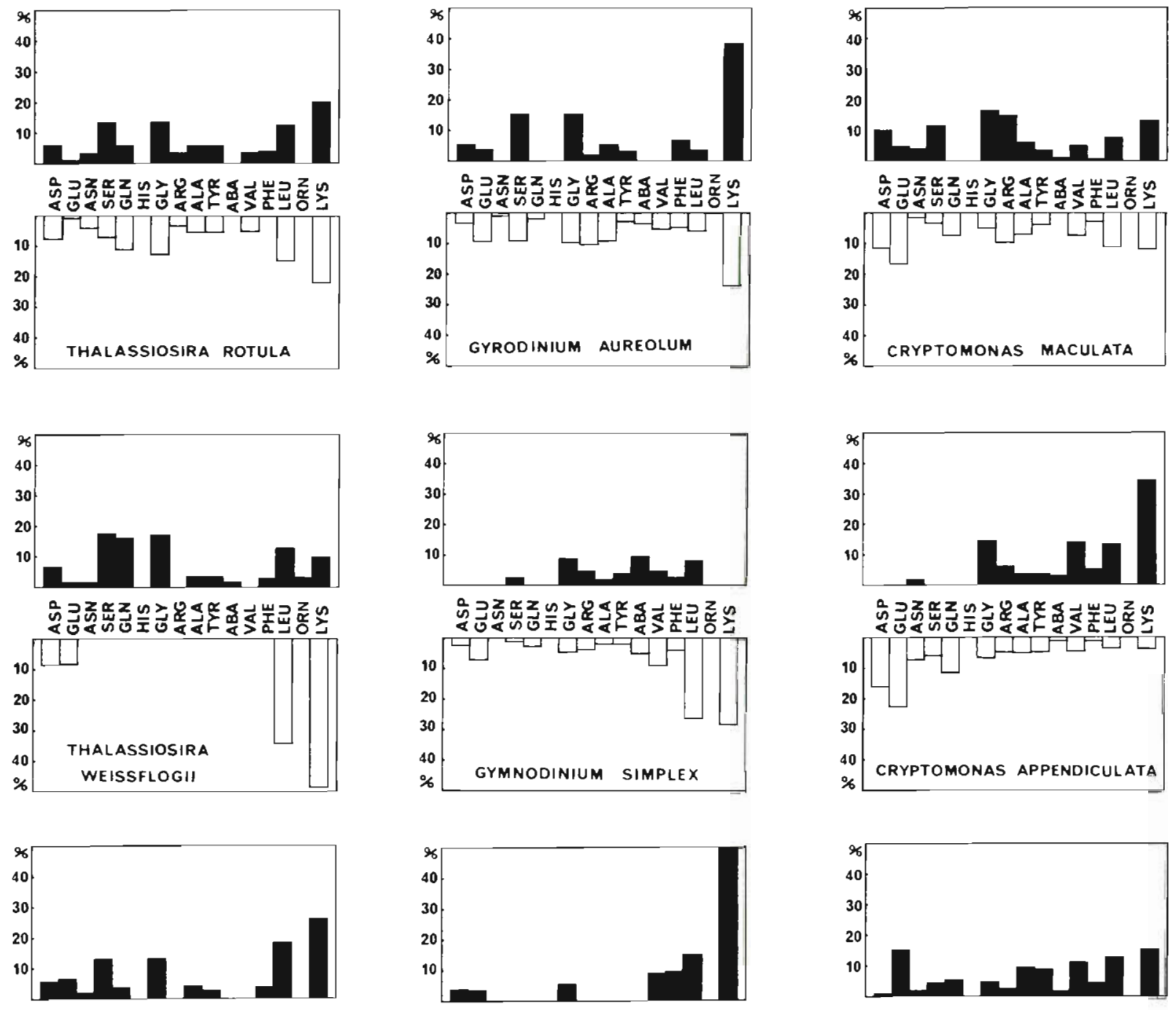

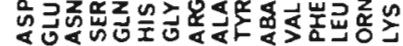
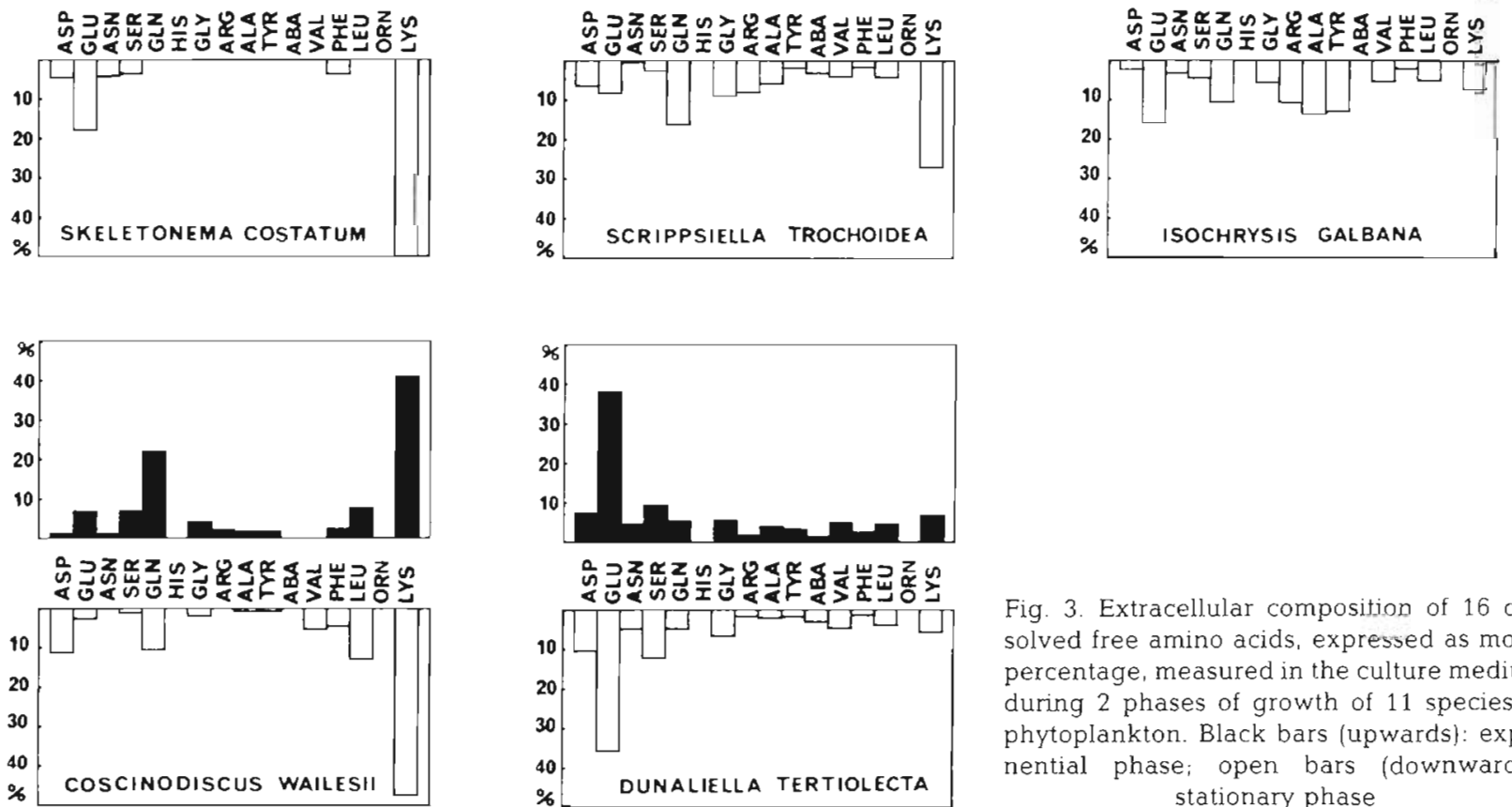

Fig. 3. Extracellular composition of 16 dissolved free amino acids, expressed as molar percentage, measured in the culture medium during 2 phases of growth of 11 species of phytoplankton. Black bars (upwards): exponential phase; open bars (downwards): stationary phase 

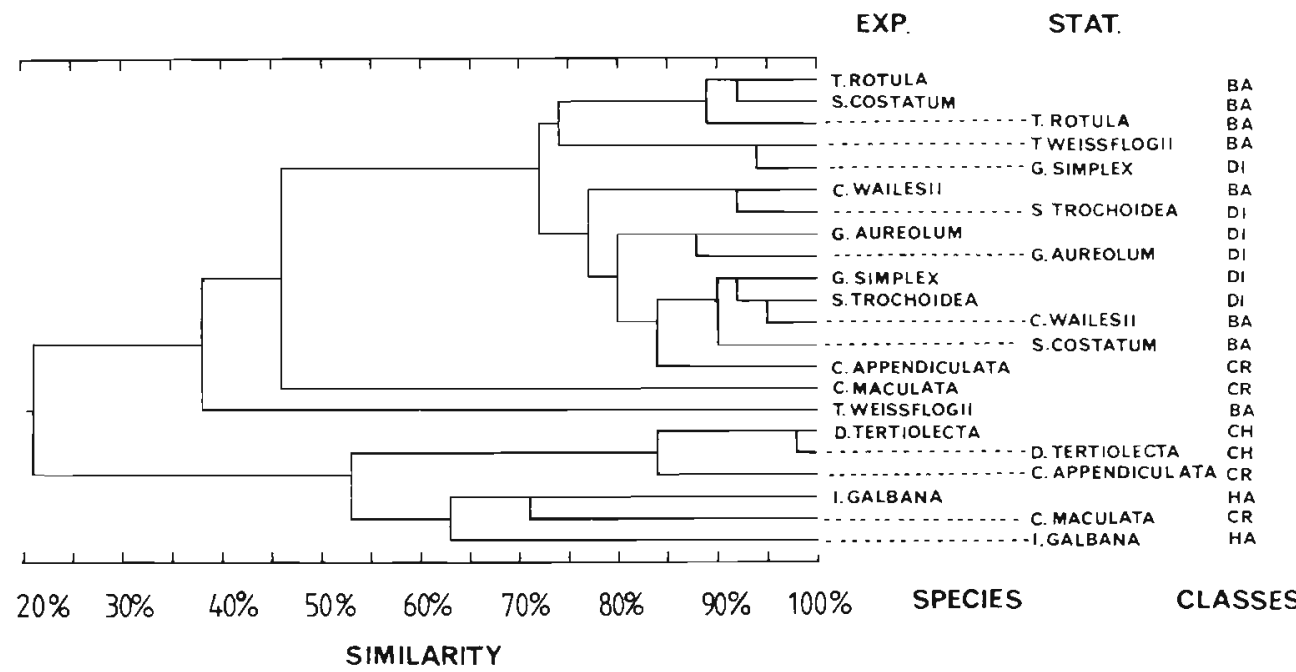

Fig. 4. Test of similarity comparing extracellular dissolved free amino acids (as in Fig. 3) of 11 species of phytoplankton during the exponential (EXP) and stationary (STAT.) phases of growth. Taxonomic classes: BA, Bacillariophyceae; DI, Dinophyceae; CR, Chryptophyceae; CH, Chlorophyceae; HA, Haptophyceae

(Fig. 1) are different. Twenty yr ago, Chau et al. (1967) found no differences between algae in relation to their combined amino acids compositions. Similar conclusions were reached earlier by Parsons et al. (1961). The major amino acids measured in the combined fraction were LEU, ALA, ASP, GLU, GLY, LYS and ARG. Enright et al. (1986) also noticed that the combined fraction was relatively stable and uniform among phytoplankton, with ASP, GLU and LEU forming the majority of the concentration. Therefore, the pool of free amino acids is variable, while the pool of combined amino acids is not, both with regard to the size and the species of phytoplankton.

The range of DFAA concentrations in the intracellular pool (Table 1 ) is similar to that reported by previous authors (Table 3). This pool (Figs. 1 and 2) results from the balance between the cellular accumulation and metabolic utilization of DFAA during protein synthesis and incorporation in the different constituents of the cell. It is mainly related to the nitrogen metabolism of the phytoplankton (Table 3). The accumulation of amino acids is controlled by the intracellular nitrogenous pools, such as $\mathrm{NH}_{4}^{+}$and proteins (Dortch 1982, Dortch et al. 1984). The intracellular DFAA/protein ratio (Table 4) changed according to both the phase of growth and to the phytoplankton species. According to Dortch et al. (1985), this ratio is an index of the nitrogen status of the cells, characterizing the gradual incorporation of DFAA in the cellular constituents during the phase of growth.

In addition, the specific rate of DFAA incorporation among the taxonomic groups of algae (Table 4) can change according to the dependence of the cell cycle on nutrient or light (Wheeler et al, 1983, Vaulot et al. 1987). Therefore, under similar conditions in culture, cellular accumulation of DFAA and protein synthesis may be different, depending on the species. Composition of the free pool of amino acid is also related to the pattern or carbon metabolism. Incorporation of carbon in the 3-phosphoglycerate cycle is reflected by the accumulation of glycerol and some amino acids (SER, ALA, GLY) as shown in the Chlorophyceae and Haptophyceae. Incorporation of carbon in the Krebs cycle also gives rise to a higher diversity of amino acids, as shown in the Bacillariophyceae by Beardall et al. (1976) and Mortrain-Bertrand et al. (1987).

The steady state of the free pool is related to the incorporation of nitrogen in the cell constituents (Turpin \& Harrison 1978, Dortch et al. 1984). Only a small proportion of free soluble amino acids is involved in the metabolism and protein synthesis of the cell, whereas the majority is apparently metabolically inert (Wiemken \& Dürr 1974). The amino acids (GLU, ALA) preferentially incorporated into protein form the 'metabolic pool' located in the cytoplasm, while basic amino acids (ARG, LYS, ORN) are constituents of the 'storage pool' located in the vacuole (Oaks \& Bidwell 1970, Wiemken \& Dürr 1974, Wheeler \& Stephens 1977. Matile 1978). When the amount of nitrogen available to the cells is not sufficient, the intracellular DFAA may act as a nitrogen buffer with amino acids from the 'storage pool' refilling the 'metabolic' pool (Matile 1978). Thus, the concentration of some specific amino acids can vary in relation to nitrogen status, and to the metabolic and catabolic utilization of amino 


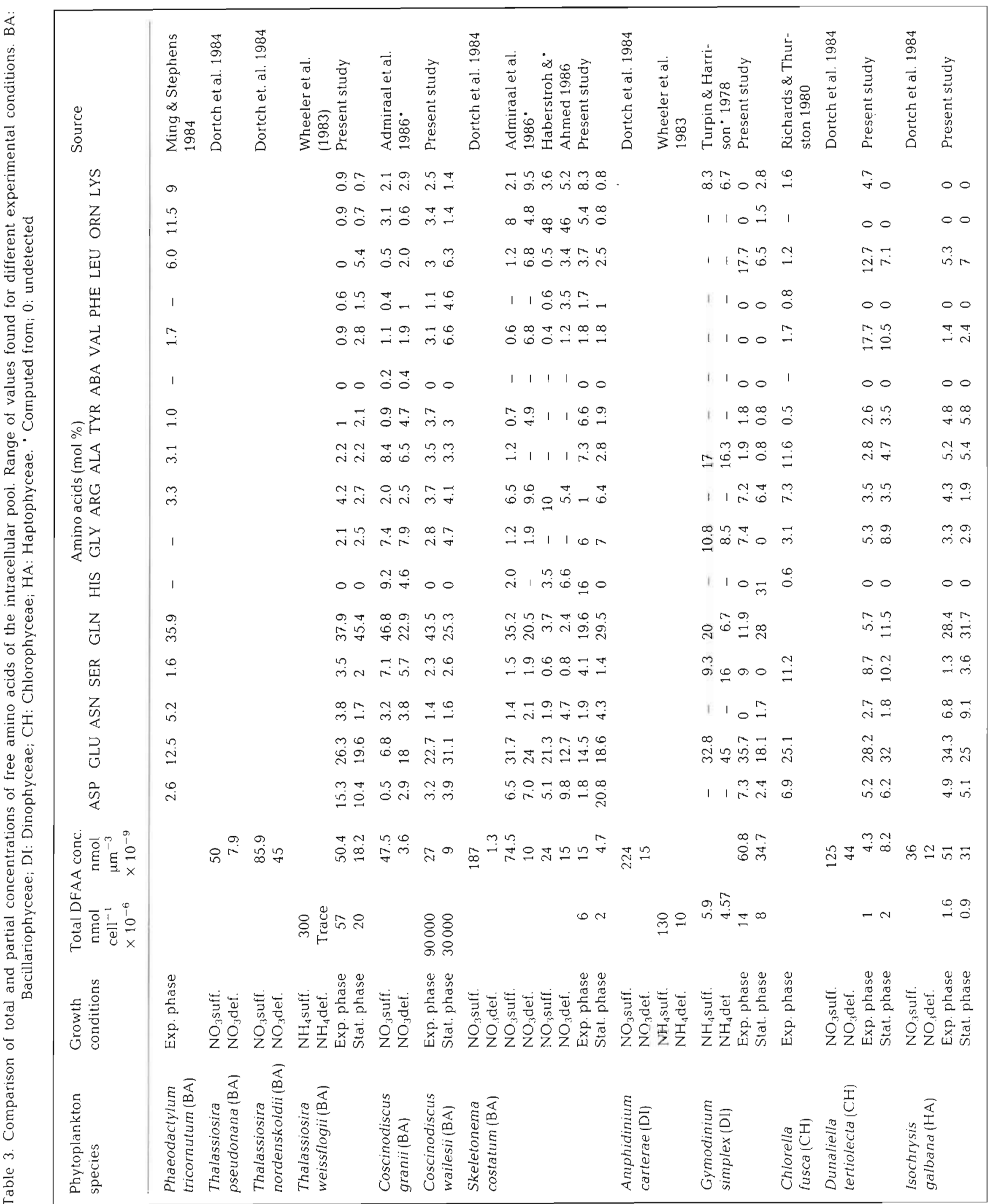


Table 4. Ratio of free amino acids to proteins concentration, measured in 11 species of phytoplankton during the exponential and stationary phases of growth. Values are in percent of total proteins per cell (Moal et al. 1987)

\begin{tabular}{|c|c|c|}
\hline \multirow[t]{2}{*}{ Phytoplankton species } & \multicolumn{2}{|c|}{ Growth phases } \\
\hline & Exponential & Stationary \\
\hline Thalassiosira rotula & 2.4 & 1.6 \\
\hline Thalassiosira weissflogii & 3.1 & 2.1 \\
\hline Skeletonema costatum & 5.4 & 2.7 \\
\hline Coscinodiscus wailesii & 5.0 & 2.2 \\
\hline Gyrodinium aureolum & 2.2 & 6.1 \\
\hline Gymnodinium simplex & 1.2 & 1.6 \\
\hline Scrippsiella trochoidea & 3.0 & 1.8 \\
\hline Cryptomonas maculata & 1.3 & 4.1 \\
\hline Cryptomonas appendiculata & 1.6 & 1.1 \\
\hline Dunaliella tertiolecta & 0.2 & 0.4 \\
\hline Isochrysis galbana & 1.7 & 1.2 \\
\hline
\end{tabular}

acids originating from the 'metabolic' and 'storage' pools. Such mechanisms have been illustrated by Admiraal et al. (1986), who showed, in Bacillariophyceae, that nitrogen reduction in the culture medium had a major influence on the cellular concentration of GLU, HIS, GLN and ARG. There was little effect on the intracellular amounts of TYR, LYS, LEU and isoleucine.

Results in Figs. 1 to 4 demonstrate that the intra- and extracellular DFAA compositions are different, and that both are species specific for phytopianktonic celis in culture. Flynn \& Butler (1986) came to similar conclusions for phytoplankton in natural conditions. However, DFAA composition could be identical between the 2 pools under special circumstances, such as leakage from senescent or damaged cells (Fuhrman \& Bell 1985).

The extracellular chemical composition measured in the culture medium, or in seawater, reflects several patterns, which are not easy to differentiate. Hammer \& Brockmann (1983) have reported that the presence of LYS, GLY, SER, ALA and VAL in the culture medium corresponds with cell division; while accumulation of LEU and GLU was in phase with the light period. Under large enclosure experimental conditions, it was demonstrated that low $\mathrm{C} / \mathrm{N}$ amino acids (e.g. LYS) prevailed in the extracellular pool and were characteristic of high biosynthetic activity of the cells. Conversely, high $\mathrm{C} / \mathrm{N}$ amino acids (e.g. ASP and GLU) accumulated at the end of the growth period, due to proteolytic liberation (Hammer et al. 1981, Hammer \& Kattner 1986). Therefore, the accumulation of specific amino acids in the water reflects the metabolism and growth phase of the cells.

Excretion and reabsorption of amino acids by algae can modify the composition of the extracellular pool (Hellebust \& Guillard 1967, Hellebust 1978, Bonin \& Maestrini 1981, Ming \& Stephens 1984, Admiraal et al. 1984, 1986, Flynn \& Syrett 1986, 1986a, b, Syrett et al. 1986). Our measurements (Fig. 3; Table 2) reflect the net concentration of DFAA, probably resulting from the balance between excretion and heterotrophic utilization. Obviously, there is some variability due to species and classes of algae (Fig. 4). Wheeler et al. (1974) and Turner (1979) mentioned that ASP and GLU are generally not utilized, except by Chlorophyceae and pennate Bacillariophyceae. Amides, GLN, ASN, GLY, SER and ALA are good nitrogenous sources during algal growth, and therefore could be preferentially absorbed by the cells (Syrett 1981, Ming \& Stephens 1985). In general, the selective absorption of basic amino acids is maximum when phytoplankton are facing an $\mathrm{N}$-deprivation situation (North \& Stephens 1972, Neilson \& Lewin 1974, Admiraal et al. 1984, Ming \& Stephens 1984).

The external pool of DFAA also reflects the heterotrophic competition between phytoplankton and bacterial activity. Uptake of amino acids by bacteria has been extensively documented (e.g. Crawford et al. 1974, Amano et al. 1982, Jørgensen et al. 1983, Carlucci et al. 1985, 1986). It may be related to the growth phase of the algae (Fukami et al. 1985) and can also vary depending on the type of bacteria - free or attached to particles (Bright \& Fletcher 1983). The selection of amino acids by bacteria can be extremely diversified (Meyer-Rell et al. 1979, Kurchman \& Hodson 1986). Bacteria may also add supplementary amino acids to the external pool by biodegradation of protein (Hollibaugh \& Azam 1983). This activity is generally reflected by the addition of enzymatic degradation, in the form of 2 decarboxylation products (ALA for ASP and $A B A$ for GLU) and of one decomposition product (ORN from ARG).

Natural decay of proteinaceous material is also involved in the transformation of the pool of DFAA in seawater. The amino acids accumulating in the water are thus GLY, ASP, ALA, SER, GLU and threonine (Lee \& Cronin 1984, Müller et al. 1986).

In nature, these various sources and factors, such as those listed above, may all occur simultaneously in the formation of the external DFAA composition. Although they are rather difficult to distinguish from each other, DFAA are always the signature of plankton activity.

Acknowledgements. We thank P. A. Course for providing phytoplankton cultures. This is a publication of the Groupe Régional d'Etudes Pélagiques Manche Atlantique (GREPMA). Financial support was received from the Ministry of Agriculture, Food and Fisheries (UK), and through the ATP Réseau trophique of CNRS (ATP no, 9-84-07) 


\section{LITERATURE CITED}

Admiraal, W., Laane, R. W P. M., Peletier, H. (1984). Partici pation of diatoms in the amino acid cycle of coastal waters uptake and excretion in cultures. Mar. Ecol. Prog. Ser 15 303-306

Admiraal, W., Peletier, H., Laane, R. W. P. M. (1986). Nitrogen metabolism of marine plankton diatoms; excretion, assimilation and cellular pools of free amino acids in seven species with different cell sizes. J. exp. mar. Biol. Ecol. 98: $241-263$

Amano, M., Hara, S., Taga, N. (1982). Utilization of dissolved amino acids in seawater by marine bacteria. Mar. Biol. 68: $31-36$

Beardall, J., Mukerji, D., Glover, E., Morris, I. (1976). The path of carbon in photosynthesis by marine phytoplankton. J. Phycol. 12: 409-417

Bonin, D. J., Maestrini, S. Y. (1981). Importance of organic nutrients for phytoplankton growth in natural environment implications for algal species succession. In: Platt, T. (ed.) Physiological bases of phytoplankton ecology. Can. Bull. Fish. Aquat. Sci. 210: 279-291

Braven, J., Evens, R., Butler, E. I. (1984). Amino acids in seawater. Chem. Ecol. 2: 11-21

Bright, J. J., Fletcher, M. (1983). Amino acid assimilation and electron transport system activity in attached and freeliving marine bacteria. Appl. environ. Microbiol. 45: 818-825

Carlucci, A. F., Craven, D. B., Henrichs, S. M. (1985). Surfacefilm microheterotrophs: amino acid metabolism and solar radiation effects on their activities. Mar Biol. 85: 13-22

Carlucci, A. F., Craven, D. B., Robertson, K. J., Henrichs, S. M. (1986). Microheterotrophic utilization of dissolved free amino acids in depth profiles of Southern California Borderland basin waters. Oceanologica Acta 9: 89-96

Chau, Y K., Chuecas, L., Riley, J. P. (1967). The component combined amino acids of some marine phytoplankton species. J. mar biol. Ass. U. K. 47: 543-554

Clifford, H. T., Stephenson, W. (1975). An introduction to numerical classification. Academic Press, New York

Crawford, C. C., Hobbie, J. E., Webb, K. L. (1974). The utilization of dissolved free amino acids by estuarine microorganisms. Ecology 55: 551-563

Daumas, R. (1976). Variations of particulate proteins and dissolved amino acids in coastal sea water Mar Chem. 4: $225-242$

Dawson, R., Kalbfleisch, J., Liebezeit, G., Llewellyn, C. A., Mantoura, R. F. C., Moreau, F., Poulet, S. A. (1985). HPLC analyses of dissolved free amino acids, pigments and vitamins in plankton and particles. Actualités de biochimie marine, Vol. 7. Oceanis 11: 365-531

Dortch, Q. (1982). Effect of growth conditions on accumulation of internal nitrate, ammonium, amino acids, and proteins in three marine diatoms. J. exp. mar. Biol. Ecol. 61: 243-264

Dortch, Q., Clayton, J. R., Jr, Thoresen, S. S., Ahmed, S. I. (1984). Species differences in accumulation of nitrogen pools in phytoplankton. Mar Biol. 81: 237-250

Dortch, Q., Clayton, J. R., Jr, Thoresen, S. S., Cleveland, J. S., Bressler, S. L., Ahmed, S. I. (1985). Nitrogen storage and used of biochemical indices to assess nitrogen deficiency and growth rate in natural piankton populations. $J$. mar Res. 43: 437-464

Enright, C. T., Newkirk, G. F., Craigie, J. S. Castell, J. C. (1986). Evaluation of phytoplankton as diets for juvenile Ostrea edulis. L. J. exp. mar Biol. Ecol. 96: 1-1.3

Flynn, K. J., Butler, I. (1986). Nitrogen sources for the growth of marine microalgae: role of dissolved free amino acids. Mar. Ecol. Prog. Ser 34: 281-304

Flynn, K. J., Syrett, P. J. (1985). Development of the ability to take up L-lysine by the diatom Phaeodactylum tricornutum. Mar Biol. 89: 317-325

Flynn, K. J., Syrett, P. J. (1986a). Characteristics of the uptake system for L-lysine and L-arginine in Phaeodactylum tricornutum. Mar. Biol. 90: 151-158

Flynn, K. J., Syrett, P. J. (1986b). Utilization of L-lysine and Larginine by the diatom Phaeodactylum tricornutum. Mar Biol. 90: 159-163

Fogg, G. E. (1983). The ecological significance of extracellular products of phytoplankton photosynthesis. Botanica mar. 26: $3-14$

Fukami, K., Simidu, U., Taga, N. (1985). Microbial decomposition of phyto- and zooplankton in seawater. II. Changes in the bacterial community. Mar. Ecol. Prog. Ser. 21: 7-13

Fuhrman, J. (1987). Close coupling between release and uptake of dissolved free amino acids in seawater studied by an isotope dilution approach. Mar. Ecol. Prog. Ser. 37: 45-52

Fuhrman, J. A., Bell, T. M. (1985). Biological considerations in the measurement of dissolved free amino acids in seawater and implications for chemical and microbiological studies. Mar. Ecol. Prog. Ser 25: 13-21

Guillard, R. R. L., Ryther, J. H. (1962). Studies of marine planktonic diatoms. I. Cyclotella nana Hustedt und Detonula confervacea (Cleve) Gran. Can. J. Microbiol. 8: 229-239

Haberstroh, P. R., Ahmed, S. I. (1986). Resolution by high pressure liquid chromatography of intracellular and extracellular free amino acids of a nitrogen deficient marine diatom, Skeletonema costatum (Grev.) Cleve, pulsed with nitrate or ammonium. J. exp. mar. Biol. Ecol. 101. 101-117

Hammer, K. D., Brockmann, U. H. (1983). Rhythmic release of dissolved free amino acids from partly synchronized Thalassiosira rotula under nearly natural conditions. Mar. Biol. 74: 305-312

Hammer, K. D., Brockmann, U. H., Kattner, G. (1981). Release of dissolved free amino acids during a bloom of Thalassiosira rotula. Kieler Meeresforsch. (Sonderh.) 5: 101-109

Hammer, K. D., Eberlein, K. (1981). Parallel experiments with Thalassiosira rotula in outdoor plastic tanks: development of dissolved free amino acids during an algal bloom. Mar Chem. 10: 533-544

Hammer, K. D., Kattner, G. (1986). Dissolved free amino acids in the marine environment: a carbon to nitrogen ratio shift during diatom blooms. Mar. Ecol. Prog. Ser. 31: 35-45

Hellebust, J. A. (1978). Uptake of organic substrates by Cyclotella cryptica (Bacillariophyceae): effect of ions, ionophores and metabolic and transport inhibitors. J. Phycol. 14: 79-83

Hellebust, J. A., Guillard, R. R. L. (1967). Uptake specificity for organic substrates by the marine diatom Melosira nummuloides. J. Phycol. 3: 132-136

Hollibaugh, J. T., Azam, F. (1983). Microbial degradation of dissolved proteins in seawater Limnol. Oceanogr 28: $1104-1116$

Jørgensen, N. O. G. (1982). Heterotrophic assimilation and occurrence of dissolved free amino acids in a shallow estuary. Mar. Ecol. Prog. Ser. 8: 145-159

Jorgensen, N. O. G., Sondergaard, M., Hansen, H. J., Bosselmann, S., Riemann, B. (1983). Diel variation in concentration, assimilation and respiration of dissolved free amino acids in relation to planktonic pnmary and secondary production in two eutrophic lakes. Hydrobiologia 107: $107-122$ 
Keller, M. D., Mague, T H., Badenhausen, M., Glover, H. E (1982). Seasonal variations in the production and consumption of amino acids by coastal microplankton. Estuar. coast. Shelf Sci. 15: 301-315

Kirchman, D. L., Hodson, R. E. (1986). Metabolic regulation of amino acid uptake in marine waters. Limnol. Oceanogr. 31: $339-350$

Laanbroek, H. J., Verplanke, J. C., de Visscher, P. R. M., de Vuyst, R. (1985). Distribution of phyto- and bacteria plankton growth and biomass parameters, dissolved inorganic nutrients and free amino acids during a spring bloom in the Oosterschelde basin, The Netherlands. Mar. Ecol. Prog. Ser. 25: 1-11

Lampert, W. (1978), Release of dissolved organic carbon by grazing zooplankton. Limnol. Oceanogr. 23: 831-832

Lancelot, C., Billen, G. (1984). Activity of heterotrophic bacteria and its coupling to primary production during the spring phytoplankton bloom in the southern bight of the North Sea. Limnol. Oceanogr. 29: 721-730

Lee, C., Cronin, C. (1984). Particulate amino acids in the sea: effects of primary productivity and biological decomposition. J. mar. Res. 42: 1075-1097

Liebezeit, G. (1985). Analysis of amino compounds by highperformance liquid chromatography. A review with emphasis on marine samples. Actualités de biochimie marine, Vol. 7, Oceanis 5: 365-433

Lindroth, P., Mopper, K. (1979). High performance liquid chromatography determination of subpicomole amounts of amino acids by precolumn fluorescence derivatization with O-phtaldialdehyde. Analyt. Chem. 51: 1667-1674

Macko, S. A., Green, E. J. (1982). An investigation of the dissolved free amino acids and their relation to phytoplankton cell density in the Damariscotta river estuary, Maine. Estuaries 5: 68-73

Matile, P. (1978). Biochemistry and function of vacuoles. Ann. Rev. Plant Physiol. 29: 193-213

vieyer-Reil, L.A., Bölter, M., Liebezcit, G., Schramm, W. (1979). Short-term variations in microbiological and chemical parameters. Mar. Ecol. Prog. Ser. 1: 1-6

Ming, L., Stephens, G. C. (1984). Demonstration of net influx of free amino acids in Phaeodactylum tricornutum using high performance liquid chromatography. J. Phycol. 20: 584-589

Ming, L., Stephens, G. C. (1985). Uptake of free amino acids by the diatom Melosira mediocris. Hydrobiologia 128: $187-191$

Moal, J., Martin-Jézéquel, V., Harris, R. P., Samain, J. F., Poulet, S. A. (1987). Interspecific and intraspecific variability of the chemical composition of marine phytoplankton Oceanologica Acta 10: 339-346

Mortrain-Bertrand, A., Descolas-Gros, C., Jupin, H. (1987) Short-term ${ }^{14} \mathrm{C}$ incorporation in Skeletonema costatum (Greville) Cleve (Bacillariophyceae) as a function of light regime. Phycologia 26: 262-269

Müller, P. J., Suess, E., Ungerer, C. A. (1986). Amino acids and amino sugars of surface particulate and sediment trap material from waters of the Scotia Sea. Deep Sea Res. 33: 819-839

Neilson, A. H., Lewin, R. A. (1974). The uptake and utilization of organic carbon by algae: an essay in comparative biochemistry. Phycologia 13: 227-264
North, B. B., Stephens, G. C. (1972). Amino acid transport in Nitzschia ovalis Arnott. J. Phycol. 8: 64-68

Oaks, A., Bidwell, R. G. S. (1970). Compartmentation of intermediary metabolites. Ann. Rev. Plant Physiol. 21: 43-66

Parsons, T. R., Stephens, K., Strickland, J. D. H. (1961). On the chemical composition of eleven species of marine phytoplankters. J. Fish Res. Bd Can. 18: 1001-1016

Poulet, S. A., Harris, R. P., Martin-Jézéquel, V., Moal, J., Samain, J. F. (1986). Free amino acids in copepod faecal pellets. Oceanologica Acta 9: 191-197

Poulet, S. A., Martin-Jézéquel, V. (1983). Relationships between dissolved free amino acids, chemical composition and growth of the marine diatom Chaetoceros debile. Mar. Biol. 77: 93-100

Poulet, S. A., Martin-Jézéquel, V., Delmas, D. (1985). Gradient of dissolved free amino acids and phytoplankton in a shallow bay. Hydrobiologia 121: 11-17

Richards, L., Thurston, C. F. (1980). Uptake of leucine and tyrosine and their intracellular pools in Chlorella fusca var. vacuolata. J. gen. Microbiol. 121: 39-47

Syrett, P. J. (1981). Nitrogen metabolism of microalgae. In Platt, T. (ed.) Physiological bases of phytoplankton ecology. Can. Bull. Fish. aquat. Sci. 210: 182-210

Syrett, P. J., Flynn, K. J., Molloy, C. J., Dixon, G. K., Pelinska A. M. Cresswell, R. C. (1986). Effects of nitrogen deprivation on rates of uptake of nitrogenous compounds by the diatom Phaeodactylum tricornutum Bohlin. New Phytol. 102: $39-44$

Turner, M. F. (1979). Nutrition of some marine microalgae with special reference to vitamin requirements and utilization of nitrogen and carbon sources. J. mar. biol. Ass. U. K. 59: $535-552$

Turpin, D. H., Harrison, P. J. (1978). Fluctuation in free amino acid pools of Gymnodinium simplex (Dinophyceae) in response to ammonia perturbation: evidence for glutamine synthetase pathway. J. Phycol. 14: 461-464

Vaulot, D., Olson. R J. Merkel. S.; Chisholm, S. W. (1987). Cell-cycle response to nutrient starvation in two phytoplankton species, Thalassiosira weissflogii and Hymenomonas carterae. Mar. Biol. 95: 625-630

Webb, K. L., Johannes, R. R. (1967). Studies of the release of dissolved free amino acids by marine zooplankton. Limnol. Oceanogr. 12: 376-382

Wheeler, P. A., North, B. B., Stephens, G. C. (1974). Amino acid uptake by marine phytoplankters. Limnol. Oceanogr. 19: $249-259$

Wheeler, P. A., Olson, R. J., Chisholm, S. W. (1983). Effects of photocycles and periodic ammonium supply on three marine phytoplankton species. II. Ammonium uptake and assimilation. J. Phycol. 19: 528-533

Wheeler, P. A., Stephens, G. C. (1977). Metabolic segregation of intracellular free amino acids in Platymonas (Chlorophyta). J. Phycol. 13: 193-197

Wiemken, A., Dürr, M. (1974). Characterization of amino acids pools in the vacuolar compartment of Saccharomyces cere. visiae. Arch. Microbiol. 101: 45-57

Williams, R., Poulet, S. A. (1986). Relationship between the zooplankton, phytoplankton, particulate matter and dissolved free amino acids in the Celtic Sea. Mar. Biol. 90: $279-284$ 